\title{
Sod Tensile Strength, Handling Quality, and Their Interrelationship for 39 Bermudagrasses
}

\author{
Lakshmy Gopinath $^{1}$, Dennis L. Martin ${ }^{1}$, Justin Quetone Moss ${ }^{1}$, \\ Yanqi $\mathrm{Wu}^{2}$, Shuhao $\mathrm{Yu}^{3}$, and James R. Underwood ${ }^{1}$
}

\begin{abstract}
AdDitional Index wORDs. Cynodon dactylon, C. dactylon $\times$ C. transvaalensis
Summary. Suitable tensile strength is essential for sod harvest, transport, and installation. Thirty-nine bermudagrass (Cynodon sp.) entries were evaluated for sod handling quality (SHQ) and sod tensile strength (STS) during 2014-15. The SHQ (a discontinuous qualitative parameter) was evaluated using a 1 to 5 scale with $\mathbf{l}=$ complete pad separation during handling and $5=$ no cracking or separation in the sod pad with excellent quality. The STS (a quantitative parameter) was determined using the force required to shear/separate the sod pad. Sod harvests were conducted at 14, 22, and 24 months after planting (MAP). The entry, harvest date, and their interaction affected STS and SHQ. Entries OKC 1302 and 12-TSB-1 had greater STS than 'Patriot' but less STS than 'Latitude 36', 'Tifway', 'Astro', and 'TifGrand'. The seeded entry PSTR6T9S had the lowest STS and SHQ. The overall mean STS and SHQ were lowest at 22 MAP, which could be attributed to the slow recovery of the entries after Winter 2014. A strong positive correlation $(r=0.92)$ between STS and SHQ suggests that SHQ can be used as a rapid field method to estimate suitability for sod harvest. A predictive linear relationship between overall STS and overall SHQ $\left(r^{2}=0.85\right)$ found predicted STS values of $8.5,22.6,36.8$, and $51.0 \mathrm{~kg} \cdot \mathrm{dm}^{-2}$ for overall mean SHQ ratings of $2,3,4$, and 5 , respectively. The results of this work will help sod producers in cultivar selection and will aid breeders in making commercialization decisions.
\end{abstract}

$\mathrm{T}$ Turgeon (2006) defined sod as the surface layer of turf harvested for transplanting. Sod consists of the interconnected parts of turfgrass plants, the soil adhering to their roots, and the underground organs of the turf. Production of cultivated turfgrass sod on a commercial basis began around 1920 in the United States (Mitchell and Dickens, 1979). Significant expansion of the

Received for publication 21 May 2021. Accepted for publication 22 Sept. 2021.

Published online 12 November 2021.

${ }^{1}$ Department of Horticulture and Landscape Architecture, Oklahoma State University, 358 Agricul tural Hall, Stillwater, OK 74078

${ }^{2}$ Department of Plant and Soil Sciences, Oklahoma State University, 371 Agricultural Hall, Stillwater, OK 74078

${ }^{3}$ Texas A\&M AgriLife Research and Extension, 6500 W. Amarillo Boulevard, Amarillo, TX 79106

This research was supported by the National Turfgrass Evaluation Program, Oklahoma Agricultural Experiment Station, Oklahoma Turfgrass Research Foundation, and U.S. Department of Agriculture, National Institute of Food and Agriculture, Hatch project OKL02990.

L.G. is the corresponding author. E-mail: lakshmy. gopinath@okstate.edu.

This is an open access article distributed under the CC BY-NC-ND license (https://creativecommons. org/licenses/by-nc-nd/4.0/).

https://doi.org/10.21273/HORTTECH04893-21 sod industry occurred in $\approx 1950$ as a result of the advancement in the mechanization of production, such as the development of the sod cutter and the release of improved sod-forming turfgrasses. The use of sod to achieve a stable, high-quality turf instantly also contributed to the expansion. One critical consideration in the selection of turfgrasses to be grown for commercial sod production is the ability to form a suitable sod that has sufficient strength to allow intact harvest, handling, and installation (Beard and Rieke, 1969).

Sod tensile strength (STS) is defined as the resistance of sod to a minimum amount of longitudinal stress and the maximum shear force required to separate the sod (Heckman et al., 2001; McCalla et al., 2009). STS is one of the major criteria for the selection of turfgrasses for sod production (Krans et al., 1992) because it determines the ease with which the sod can be harvested and transported. Sod with a weak STS will break apart easily. The STS of turfgrasses has been measured using quantitative measuring devices in the past (Begitschke et al., 2018; Friell et al., 2017; Goatley and Schmidt, 1991; Hall, 1980; Han, 2009; McCalla et al., 2009; Parish, 1995; Segars et al., 2020; Shildrick, 1982; Sorochan et al., 1999). The force required to tear the sod apart was recorded and designated as the STS value of the sod pad. Sod handling quality (SHQ) has been used as a rapid, qualitative means of measuring the handling quality of sod pads (Han, 2009; Segars et al., 2020). Han (2009) developed and evaluated SHQ using a scale of 1 to 5 , in which 1 had the least and 5 had the best handling quality.

Bermudagrass (Cynodon sp.) is the most widely adapted warm-season turfgrass, especially in the U.S. transition zone. Common bermudagrass $(C$. dactylon) and african bermudagrass $(C$. transvaalensis) and their interspecific hybrids are valued for use as turfgrass (Taliaferro et al., 2004). In order for private industry and university developers to make decisions concerning the suitability of their bermudagrass products in sod production, information is needed concerning the SHQ and STS of their products. The objectives of this research were to determine the STS and SHQ of 35 official entries of the 2013-17 National Turfgrass Evaluation Program (NTEP) National Bermudagrass Trial and four local entries.

\section{Materials and methods}

The experimental site was located at the Turfgrass Research Center at Oklahoma State University, Stillwater (lat. $36^{\circ} 07^{\prime} 27.4^{\prime \prime} \mathrm{N}$, long. $97^{\circ} 06^{\prime} 07$. $\mathrm{l}$ "W). The soil type was an Easpur loam (fine-loamy, mixed, superactive, thermic Flueventic Haplustoll) and a Pulaski fine sandy loam (coarse-loamy, mixed, superactive, nonacidic, thermic Udic Ustifluvents). Entries were planted by either seed or plugs in Aug. 2013. Official 2013 NTEP entries that were commercially available were interspecific hybrids ('Tifway', 'Latitude 36',

\begin{tabular}{llll}
\hline $\begin{array}{l}\text { Units } \\
\text { To convert U.S. to SI, } \\
\text { multiply by }\end{array}$ & U.S. unit & SI unit & $\begin{array}{l}\text { To convert SI to U.S., } \\
\text { multiply by }\end{array}$ \\
\hline 0.3048 & $\mathrm{ft}$ & $\mathrm{m}$ & 3.2808 \\
2.54 & inch $(\mathrm{es})$ & $\mathrm{cm}$ & 0.3937 \\
1.1209 & $\mathrm{lb} / \mathrm{acre}$ & $\mathrm{kg} \cdot \mathrm{ha}^{-1}$ & 0.8922 \\
0.0488 & $\mathrm{lb} / \mathrm{ft}^{2}$ & $\mathrm{~kg} \cdot \mathrm{dm}^{-2}$ & 20.4816
\end{tabular}


'Patriot') and common bermudagrass entries ('Celebration', 'NuMex Sahara', 'Princess 77', 'Riviera', 'Yukon', 'North Shore SLT'). The local entries (not official entries in the 2013 NTEP trial) that were also commercially available were the interspecific hybrid 'TifGrand' and 'U-3-NC', 'U-3-TGS', and 'Quickstand' common bermudagrass. Entries considered as standards for this study included 'Tifway', 'Latitude 36', 'Patriot', 'Celebration', 'Astro', 'TifGrand', and 'Quickstand'. The individual plot size was $3 \times 6 \mathrm{ft}$ and was maintained under simulated sod production conditions, with entries mowed three times per week at a height of 2.5 inches using a rotary mower. The trial was irrigated as needed to maintain vigorous growth and avoid plant wilting. The fertilizer regime was $244 \mathrm{~kg} \cdot \mathrm{ha}^{-1}$ nitrogen per year $(46 \mathrm{~N}-0 \mathrm{P}-0 \mathrm{~K})$ applied in increments from Apr. through Sept. 2014 and 2015.

Three dates of sod harvest were conducted to assess the effect of entry maturity on STS and SHQ. Harvest 1 was 14 months after planting (MAP) in late Oct. 2014; harvest 2 was conducted at $22 \mathrm{MAP}$, after $100 \%$ spring green-up, in early June 2015; and harvest 3 was conducted 24 MAP in Aug. 2015. Sod pads measuring 15 inches in length, 0.5 inch deep, and 12 inches wide were cut using a sod cutter (Ryan Junior 544844C; Textron, Racine, WI). The plots were irrigated uniformly $2 \mathrm{~d}$ before harvest to prevent the plots from being too wet at the time of harvest. Two subsamples per plot were harvested and evaluated for SHQ and STS. The tensile strength value of each subsamples was measured using an STS measuring device described by Han (2009) and Segars et al. (2020). The device was oriented vertically and operated using a similar principle described by Rieke et al. (1968) and Sorochan et al. (1999). The force at which the sod sheared, measured in peak force (kilograms), was converted to peak force per crosssectional area (kilograms per square decimeter) using the specific width and depth of the individual sod pads.

The SHQ provided a qualitative measurement of the strength of a sod pad rating and was developed at Oklahoma State University by graduate student Holly Han and turfgrass professor Dr. Dennis Martin (Han, 2009). SHQ is the ability of the harvested sod to remain intact while being lifted and transported to the site where it is ultimately used. The sod pads from each plot were lifted by hand. The sod was suspended vertically by hand, and only one end of the sod pad was given a gentle shake and was transported to the border of the block to be tested in the tearing device. Based on the transport and handling of the sod pad before testing in the tearing device, SHQ was assessed using the 1to 5-point scale described by Han (2009), where 1 is complete breakage, unable to be inserted into the STS assessment device (unacceptable quality); 2 is substantial pad cracking, but still able to be lifted and inserted in the STS device; 3 is moderate cracking (our suggested minimum acceptable for commercial use); 4 is very mild cracking (our suggested minimum rating for new cultivar commercialization); and 5 is no cracking of sod pad (best handling quality).

\section{Experimental design and statistical analysis}

The experiment was designed as a randomized complete block with a split-plot in time arrangement of treatments, with three replicate plots of each entry. Entry and replication were the main plots, with sod harvest dates as the subplots. As sod harvest dates took place on progressively more mature bermudagrass, we considered both entry and harvest date as fixed effects. The dependent variables STS and SHQ data were subjected to analysis of variance (ANOVA) using the generalized linear models procedure in SAS software (version 9.3; SAS Institute, Cary, NC). The ANOVA revealed that entry, replication, harvest date, and the interaction of entry and harvest date had significant effects on STS and SHQ. Consequently, mean STS and SHQ were separated across harvest dates, and entry means were separated for STS and SHQ within harvest dates using Fisher's protected least significant difference (LSD) test at $P \leq 0.05$. A predictive linear relationship between overall mean STS and overall SHQ that used the data for each entry averaged over the three harvest dates was developed using SAS procedure PROC CORR (SAS version 9.3The SHQ was plotted on the $x$-axis and STS was plotted on the $y$-axis. Because the data were pooled over the three harvest dates, there were no mean STS values to plot for an SHQ value of 1 point. In addition, STS values for an SHQ value of 5 points were dropped from the dataset to reduce potential biasing produced by an unbounded STS when SHQ reached but could not exceed a value of 5 points. However, the scale from 1 to 5 was included in the graph for the visual display of the predicted equation line on the chart (Fig. 1).

\section{Results and discussion}

The ANOVA on STS data revealed highly significant effects for all model terms: entry, replication, entry $\times$ replication, harvest date entry $\times$ harvest date, and replication $\times$ harvest date (entry). The overall mean bermudagrass STSs by harvest date were harvest

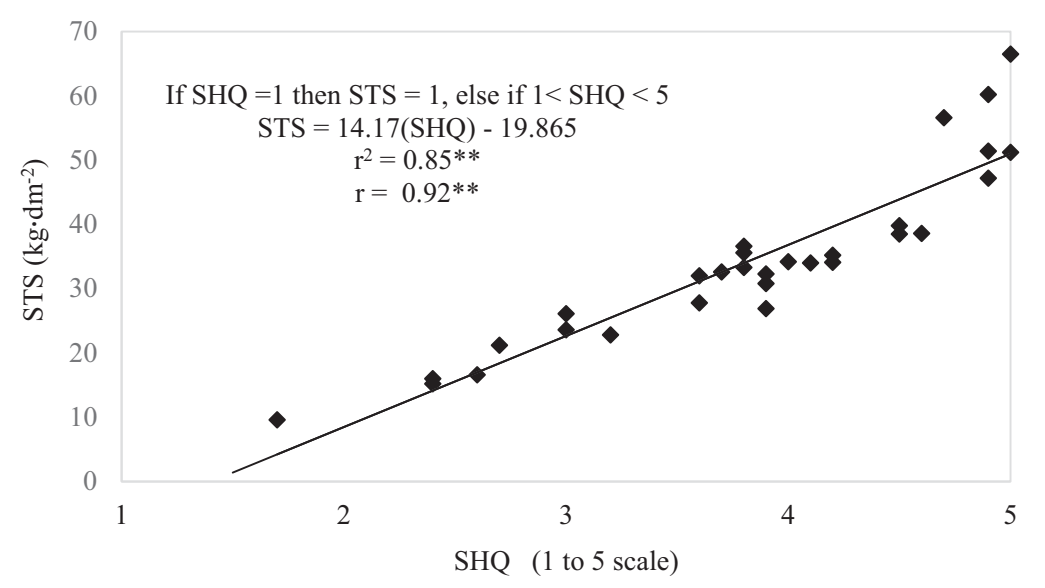

Fig. 1. Relationship between sod handling quality (SHQ) rated on a scale from 1 to 5 scale $(1=$ poor quality, complete breakage during handling; 5 = excellent, very tight, no cracking during handling) and sod tensile strength (STS) of 39 bermudagrass entries. Data points are cultivar means pooled over three assessment dates; ** indicates significance at $P=0.01 ; 1 \mathrm{~kg} \cdot \mathrm{dm}^{-2}=20.4816 \mathrm{lb} / \mathrm{ft}^{2}$. 
Table 1. Mean sod tensile strength of 39 bermudagrass entries pooled over three harvest and within three harvest dates at Stillwater, OK.

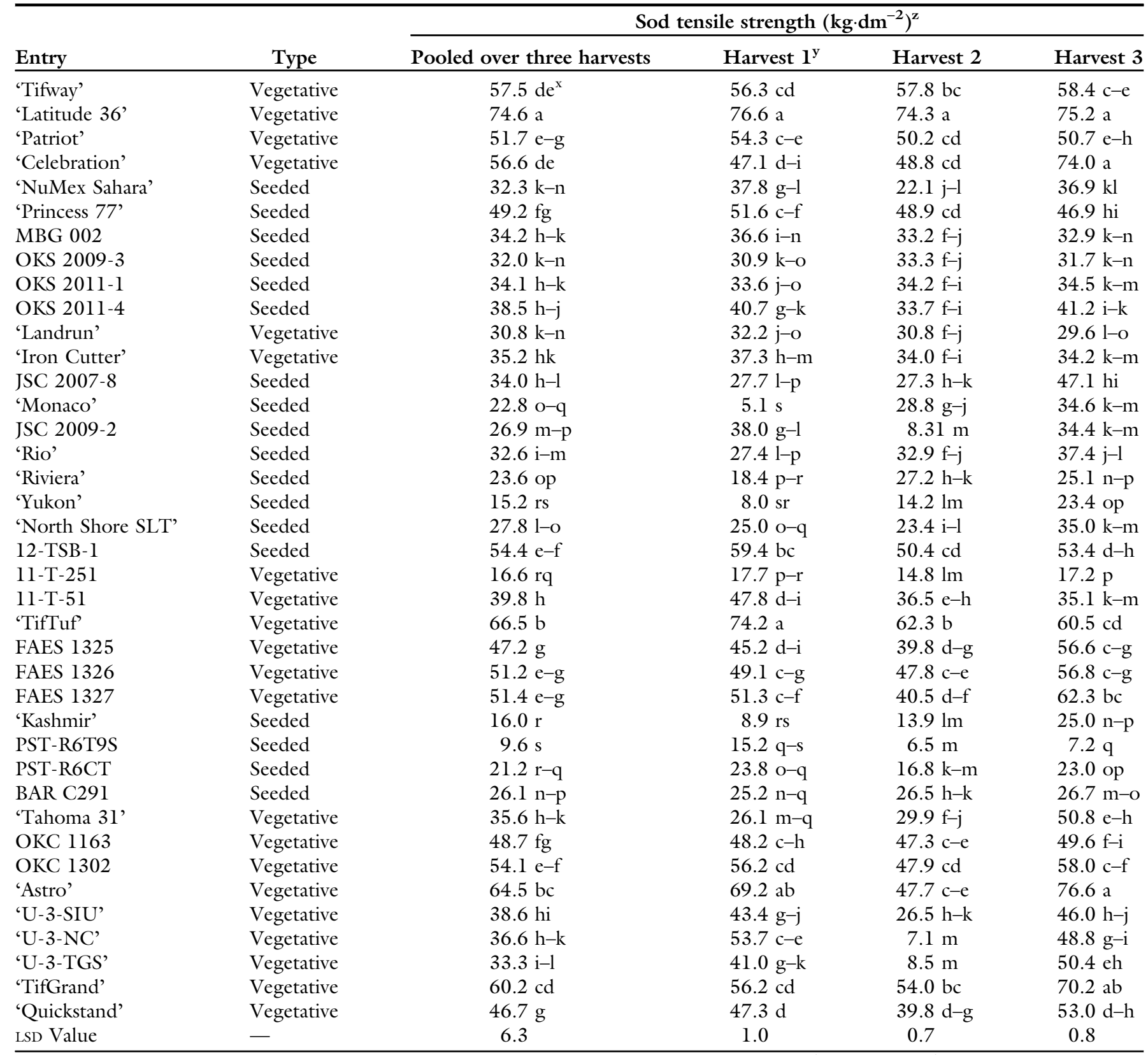

${ }^{2}$ Sod tensile strength reported for sod pads measuring 0.5 -inch depth and 12 -inches width; 1 inch $=2.54 \mathrm{~cm}, 1 \mathrm{~kg} \cdot \mathrm{dm}^{-2}=20.4816 \mathrm{lb} / \mathrm{ft}^{2}$.

y'Sod was harvested using a walk-behind sod cutter in Oct. 2014, June 2015, and Aug. 2015. Means are the average of three replications per harvest date with two subsamples per observation.

${ }^{x}$ Means within the same column followed by the same letter are not significantly different at the $P \leq 0.05$ level using Fisher's protected least significant difference (LSD) test.

$3\left(43.9 \mathrm{~kg} \cdot \mathrm{dm}^{-2}\right)>$ harvest $1(39.6$ $\left.\mathrm{kg} \cdot \mathrm{dm}^{-2}\right)>$ harvest $2\left(34.1 \mathrm{~kg} \cdot \mathrm{dm}^{-2}\right)$ $(\mathrm{LSD}=3.2, P \leq 0.05)$. The overall mean STS of entries ranged from a low of $9.6 \mathrm{~kg} \cdot \mathrm{dm}^{-2}$ (PST-R6T9S) to a high of $74.6 \mathrm{~kg} \cdot \mathrm{dm}^{-2}$ ('Latitude 36') (Table 1). 'Latitude 36', 'TifGrand', 'Tifway', 'Astro', 'Patriot', and 'Celebration' were in the group of top performers. 'Latitude 36', with an overall STS value of $76.7 \mathrm{~kg} \cdot \mathrm{dm}^{-2}$, was the best-performing cultivar and had an STS significantly greater than all other cultivars. 'Riviera', a standard seeded entry in the 2013 NTEP trial, was found in a lower statistical group. These results are consistent with the findings of Han (2009), in which 'Latitude 36' [synonym OKC 1119 in Han (2009)] was in the top statistical group, and 'Riviera' was in the lowest statistical group. In our study, after 'Latitude 36', the relatively new bermudagrass cultivar TifTuf (DT-1) had a significantly grea- ter overall STS than the rest of the cultivars except for 'Astro'. 'Tifway' and 'Astro' did not differ significantly. Entries that were not different from the industry standards 'Tifway' and 'Patriot' were OKC 1302, FAES 1326, FAES 1327, and 12-TSB-1.

Because of the highly significant effects of harvest date on STS, a separate ANOVA was conducted on data within each harvest date (Table 1). The entry mean separations for STS values 
for individual harvests are reported in Table 1. Entries that exhibited a trend of increasing numeric STS over harvests 1 through 3 were 'Celebration', JSC 2007-8, 'Monaco', 'Rio', 'Yukon', 'Kashmir', 'Tahoma 31' (OKC 1131), and 'Quickstand'. This trend could be attributed to the entries being better established by the third harvest date than their maturity at the two earlier harvest dates. The vegetatively propagated cultivars, in general, had the greatest STS in our study. Although seeded cultivars generally exhibited lower mean STS values throughout the trial than vegetatively propagated cultivars, the seeded cultivars 12-TSB-1 and Princess 77 exhibited a greater STS value and were not different from the vegetative cultivars Tifway and Patriot over the three harvest dates. The seeded cultivars PST-R6T9S and Kashmir were in the lowest statistical group for STS at all harvest dates, which is in accordance with the findings of McCalla et al. (2009), who found that seeded cultivars had lower sod strength and required netting to obtain satisfactory harvest characteristics in sod production. Vegetative cultivars would be expected to produce enhanced vegetative growth in leaves, stolons, rhizomes, and roots relative to seeded types, which tend to continue to invest in increased seed-head production relative to vegetatively propagated types (Hensler et al., 1999).

The ANOVA on SHQ data revealed highly significant effects for all model terms: entry, replication, entry $\times$ replication, harvest date, entry $\times$ harvest date, and replication $\times$ harvest date (entry). The overall mean bermudagrass $S H Q$ ratings by harvest date were harvest 3 (4.3 rating) > harvest 1 (4.1 rating) $>$ harvest 2 (3.8 rating $)(\mathrm{LSD}=0.2, P \leq 0.05)$, similar to the overall mean STS by harvest date. The lower STS and SHQ mean of harvest 2 could be a result of the slow recovery of the entries after Winter 2014. Therefore, although the canopy showed $100 \%$ green-up, the shoots, stolons, rhizomes, and roots responsible for STS may not have reached the stage of development in June 2015 that was present at the time of harvest in Oct. 2014 (Beard and Rieke, 1969). The mean SHQ of the 39 bermudagrass entries pooled over three harvest dates (Table 2) ranged from 1.7 to 5.0. Fifty-six percent of the entries provided good to excellent sod handling quality $(\geq 4.0)$. As a result of the significant effect of harvest date and the entry $\times$ harvest date on SHQ, a separate ANOVA was conducted within each harvest date. The entry mean separation for SHQ values within harvests is also presented in Table 2. Table 2 also shows the number of times an entry appeared in the top statistical group for SHQ. 'Tifway', 'Latitude 36', 'Patriot', 'Princess 77', 12-TSB-1, 'TifTuf', FAES 1326, OKC 1163 , OKC 1302, 'Astro', 'Quickstand', 'Celebration', 'TifGrand', 'U-3-SIU', FAES 1327, 11-T-51, and FAES 1325 were in the top statistical group for all three harvest dates. Among these entries, 'Tifway', 'Latitude 36', 'Patriot', 'Princess 77', 12-TSB-1, 'TifTuf', FAES 1326, OKC 1163 , OKC 1302, 'Astro', and 'Quickstand' consistently scored an SHQ of 5 points during all harvests. It is important to note that 'Princess 77' and 12TSB-1 were the only seeded entries to have scored a mean SHQ of 5 points and were in the top statistical group for all three harvests, as seeded entries have reduced rhizome development (Hensler et al., 1999).

Entries able to provide $\mathrm{SHQ}$ meeting or exceeding the minimum acceptable SHQ by the first harvest at 14 MAP are of great interest because they did not require additional maturity to be harvested. Such cultivars might be more profitable than cultivars requiring a longer cropping cycle to achieve satisfactory handling quality, provided all other performance parameters are satisfactory. 'Latitude 36' and 'Tifway' were in the top statistical group and were similar to the results reported by Han (2009) and Segars et al. (2020). Seeded cultivars are generally believed to have a lower STS and SHQ as a result of reduced rhizome development (Hensler et al., 1999; Munshaw et al., 2001). In our study, the cultivars that never appeared in the top statistical group for all three harvest dates were the seeded cultivars PST-R6T9S, Kashmir, PST-R6CT, Yukon, Riviera, BAR C291, Rio, OKS 2009-3, and MBG 002 , and the clonal entry 11-T-251. However, not being in the top statistical group for all three harvest dates does not mean these entries must have a low value for the SHQ value.
Forty-nine percent of the entries were able to provide a mean handling quality of 4 points or more during all three harvests (Table 2) and included MBG 002, OKS 2011-1, OKS 2011-4, and 'U-3-NC'. 'NuMex Sahara', JSC 2009-2, FAES 1327, PST-R6T9S, PST-R6T9S, 'U-3-NC', 11-T-251, and 'U-3-TGS' had a lower SHQ in the second harvest than in the first and third harvests. This trend could be attributed to the slow recovery of the entries that we observed after Winter 2014. 'Kashmir', 'PSTR6CT', 'Tahoma 31', 'Monaco', 'Yukon', 'Rio', and 'North Shore SLT' showed an increasing trend of a greater mean SHQ from the first to the third harvest date. 'Monaco' and 'North Shore SLT' were able to reach the top statistical group in the final harvest date. By the final harvest date, 'Yukon', PST-R6CT, and 'Kashmir' achieved an SHQ value that was the minimum suggested for satisfactory handling. The ability of these cultivars to achieve a greater $\mathrm{SHQ}$ rating by the final harvest date could be attributed to a more mature and robust stand.

Pearson's correlation coefficient $(r)$ for the relationship between mean SHQ and mean STS was 0.92 at $P \leq$ 0.001 , revealing a strong positive correlation between the two parameters (Fig. 1). The $r^{2}$ value of this equation was 0.85 and is similar to the value (0.89) obtained by Han (2009). However, the $r^{2}$ value obtained in our study was slightly greater than the value (0.65) reported by Segars et al. (2020). The strong positive correlation suggests that SHQ can help simplify tests for screening turfgrasses for acceptable sod strength because it is a rapid and easily performed test to estimate, and if requires no equipment other than a sod harvester. The predicted mean STS as a function of SHQ was 8.5, 22.6, 36.8, and $51.0 \mathrm{~kg} \cdot \mathrm{dm}^{-2}$ for an SHQ of 2,3 , 4 , and 5 , respectively. The predicted mean STS value was not calculated for an SHQ of 1 because sod with an SHQ of 1 falls apart, indicating an STS of 0 because it cannot be transported or placed into the STS measuring device for testing. It is important to note that the plotted equation line did not pass through the origin $(\mathrm{STS}=0, \mathrm{SHQ}=1)$. This could be a result of an inadequate number of observations of overall mean STS near or of zero and handling quality 
Table 2. Mean sod handling quality (SHQ) of 39 bermudagrass entries pooled over three harvest and within three harvest dates at Stillwater, OK.

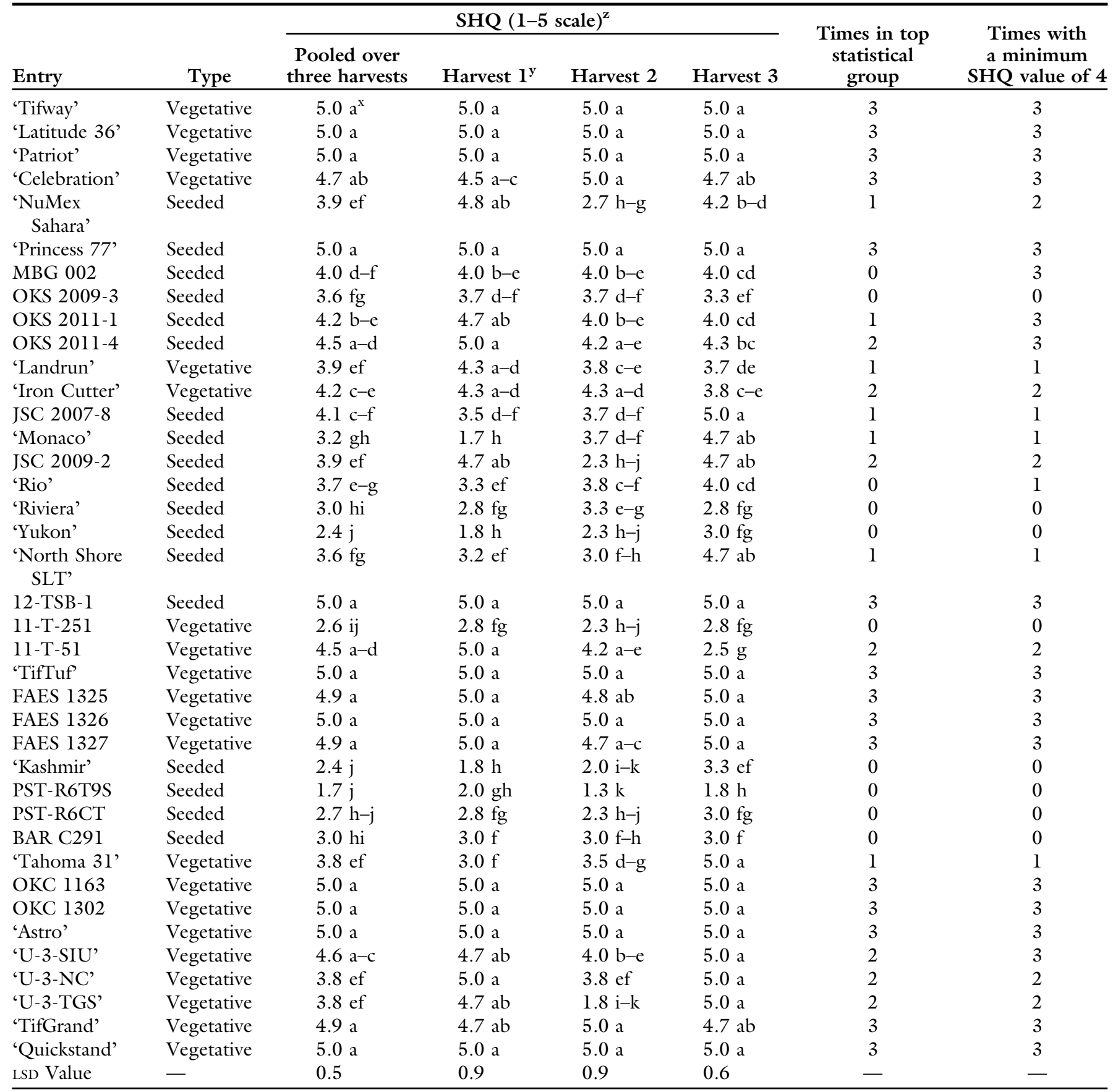

${ }^{\mathrm{z}}$ Sod handling quality was measured on a 1 to 5 scale where $\mathrm{l}=$ poor quality, complete breakage of sod during handling; 2 = fair, not commercially recommended, substantial cracking of sod during handling; 3 = good, our suggested minimum for industry handling, moderate cracking of the sod occurred; 4 = very good, minimal cracking, our suggested minimum for cultivar commercialization; and $5=$ excellent, very tight, no cracking.

${ }^{y}$ Sod was harvested using a walk-behind sod cutter in Oct. 2014, June 2015, and Aug. 2015. Means are the average of three replications per harvest date with two subsamples per observation.

${ }^{\mathrm{x}}$ Means within the same column followed by the same letter are not significantly different at the $P \leq 0.05$ level using Fisher's protected least significant difference (LSD) test.

of 1 point to weight the equation near the origin as opposed to the large number of observations of high SHQ and high STS. This is probably a result of the large number of highly advanced experimental and commercial vegetatively propagated cultivars submitted to the NTEP for national testing.
In conclusion, entry, harvest date, and their interaction strongly influenced STS and SHQ in this trial. Thirty-nine percent of the entries tested were in the top statistical group for SHQ on all three harvest dates. The vegetative entries 'Tifway', 'Latitude 36', 'Patriot', OKC 1163, OKC
1302, 'Astro', 'Quickstand', 'TifTuf', and FAES 1326; and the seeded entries 'Princess 77', 12-TSB-1 all scored 5 points on all harvest dates. Forty-nine percent of the entries tested scored at or above the suggested commercial minimum mean SHQ value of 4 in all three harvest dates. 'Latitude 
36' was consistently in the top statistical group for STS, and this is in agreement with the findings of Han (2009). The significance of this research is multifold. We affirmed the usefulness of the discontinuous qualitatively assessed parameter SHQ first developed by Han (2009). In addition, a large number of new bermudagrass cultivars were evaluated for sod production characteristics for the first time. This work is also the first to develop a predictive linear regression relationship between STS and SHQ parameters. The predictive linear equation derived between STS and SHQ needs to be tested on an independent dataset to determine its broad application or whether its use is limited to trials and conditions nearly identical to our study. When paired with findings from other multiparameter performance trials, the information gained from this research will help sod producers make more informed production decisions. The results will also assist turfgrass developers in formulating a decision on whether the experimental bermudagrass selections tested should be pursued further for possible commercial releases.

\section{Literature cited}

Beard, J.B. and P.E. Rieke. 1969. Producing quality sod, p. 442-461. In: A.A. Hanson and F.V. Juska (eds.). Turfgrass science. Agron. Mongr. 14. Amer. Soc. Agron., Crop Sci. Soc. Amer., Soil Sci. Soc. Amer., Madison, WI. https://doi. org/10.2134/agronmonogr14.c16.

Begitschke, E.G., J.D. McCurdy, T.M. Tseng, T.C. Barickman, B.R. Stewart, C.M. Baldwin, M.P. Richard, and J.K. Ward. 2018. Preemergence herbicide effects on establishment and tensile strength of sprigged hybrid bermudagrass. Agron. J. 110:
2243-2249, https://doi.org/10.2134/ agronj2017.12.0720.

Friell, J., E. Watkins, B.P. Horgan, and M. Cavanaugh. 2017. Sod strength characteristics of 51 cool-season turfgrass mixtures. Agron. J. 109:1749-1757, https:// doi.org/10.2134/agronj2016.05.0295.

Goatley, J.M. and R.E. Schmidt. 1991. Biostimulator enhancement of kentucky bluegrass sod. HortScience 26:254-255, https://doi.org/10.21273/HORTSCI.26. 3.254 .

Hall, J.R., III. 1980. Effect of cultural factors on tall fescue - kentucky bluegrass sod quality and botanical composition. Proc. Third Intl. Turfgrass Res. Conf. 3:367-377. https://doi.org/10.2135/ 1974.proc3rdintlturfgrass.c43.

Han, H.R. 2009. Development improved turf-type bermudagrasses. Oklahoma State Univ., Stillwater, master's thesis. 21 Sept. 2021. <https://hdl.handle.net/11244/ 9585>.

Heckman, N.L., G.L. Horst, R.E. Gaussoin, and K.W. Frank. 2001. Storage and handling characteristics of trinexapac-ethyl treated kentucky bluegrass sod. HortScience 36:1127-1130, https://doi.org/ 10.21273/HORTSCI.36.6.1127.

Hensler, K.L., M.D. Richardson, and J.R. Bailey. 1999. Implications of seeded bermudagrass planting date and morphology on cold tolerance, p. 69-71. In: J.R. Clark and M.D. Richardson (eds.). Horticultural studies 1998. Arkansas Agric. Exp. Sta., Res. Ser. 466. University of Arkansas, Fayetteville, AR.

Krans, J.V., H.W. Philley, J.M. Goatley, and M. Tomaso-Peterson. 1992. The relationships of rhizome density, sod strength, and spring green-up in bermudagrass. Agron. Abstr. 84:172 (abstr.).

McCalla, J., M. Richardson, J. Boyd, and A. Patton. 2009. Effect of mesotrione on sod quality of Tifway bermudagrass: Arkansas turfgrass report 2008. Arkansas Agr. Exp.
Sta. Res. Ser. 568:50-53, https://doi.org/ 10.1094/ATS-2008-0118-01-RS.

Mitchell, C.H. and R. Dickens. 1979. Nitrogen fertilization and mowing height effects on tensile strength of bermudagrass sod. Agron. J. 71:1061-1062, https://doi. org/10.2134/agronj1979.00021962007 $100060039 x$.

Munshaw, G.C., D.W. Williams, and P.L. Cornelius. 2001. Management strategies during the establishment year enhance production and fitness of seeded bermudagrass stolons. Crop Sci. 41:1558-1564, https:// doi.org/10.2135/cropsci2001.4151558x.

Parish, R.L. 1995. A simple device to measure sod strength. HortTechnology 5:308-309, https://doi.org/10.21273/ HORTTECH.5.4.308.

Rieke, P.E., J.B. Beard, and C.M. Hansen. 1968. A technique to measure sod strength for use in sod production studies. Agron. Abstr. 60:60 (abstr.).

Segars, C.A., J.Q. Moss, D.L. Martin, and Y. Wu. 2020. Sod production characteristics: How strong is your bermudagrass? Intl. Turfgrass Soc. Res. J. 1-6. https:// doi.org/10.1002/its2.4.

Shildrick, J.P. 1982. Mixtures and seed rates for sod production. J. Sports Turf Res. Inst. 58:76-95.

Sorochan, J.C., R.N. Calhoun, and J.N. Rogers. 1999. Apparatus to measure turfgrass sod strength. Agron. Abstr. 91:137 (abstr.).

Taliaferro, C.M., D.L. Martin, J.A. Anderson, M.P. Anderson, and A.C. Guenzi. 2004. Broadening the horizons of turf bermudagrass. U.S. Golf Assoc. Turf. Environ. Res. Online 3:1-9.

Turgeon, A.J. 2006. Instructional modules: Introduction to turfgrass management. Educational Resources for Turfgrass Science, University Park, PA. 30 Aug. 2021. <http://www.personal.psu. edu/faculty/a/s/asm4/turfgrass $/>$. 